\title{
Use of shelter by the small Patagonian octopus Octopus tehuelchus: availability, selection and effects on fecundity
}

\author{
Oscar Osvaldo Iribarne*
}

Instituto de Biología Marina y Pesquera 'Almirante Storni', CC 104 (8520), San Antonio Oeste, Río Negro, Argentina

\begin{abstract}
Shelters on the sandy bottom area of the Northwest San Matías Gulf (Argentina) consist mostly of shells of invertebrates. Small octopuses Octopus tehuelchus d'Orbigny use the shells of gastropods Zidona dufresnei, Odontocymbiola subnodosa and Buccinanops gradatum, barnacles Balanus sp. and clams Pitar rostratus and Amiantis purpurata. Intermediate-size octopuses use mainly oyster shells Ostrea puelchana. Large octopuses used a variety of shelters made up by parts of shells or other sources. Shells of $O$. puelchana were the most important shelter for brooding females. Most eggs (ca $90 \%$ ) were placed on the concave valve. When clams were used as the brooding shelter, however, eggs were evenly distributed between the 2 valves. The quality of shelter affects reproductive output, particularly that of larger females.
\end{abstract}

\section{INTRODUCTION}

Use of shelters is well documented for several octopus species. Spatial distribution is partially controlled by shelter availability in Octopus doffleini Wulker (Hartwick et al. 1978) and O. joubini Robson (Mather 1982). O. vulgaris Cuvier (Altman 1967), O. doffleini (Hartwick \& Thorarinsson 1978), O. bimaculatus Verrill (Ambrose 1982), O. cyanea Gray (Van Heukelen 1973), O. joubini (Mather 1982), and O. aegina Gray (EiblEibesfeldt \& Scheer 1962) select shelters. O. vulgaris modifies shelter quality (Bierens de Haan 1926).

Several shelter characteristics affect octopus preference. Size of entrances are selected for by Octopus joubini (Mather 1982), and total size of the refuge is selected for by $O$. doffleini (Hartwick et al. 1984). Blockage of light is important in $O$. vulgaris (Bierens de Haan 1926) and O. joubini (Mather 1982).

This study assesses the importance of and characterizes the use of shelter by Octopus tehuelchus d'Orbigny. This is a small species distributed in the Southwestern Atlantic from southern Brazil $\left(30^{\circ} \mathrm{S}\right)$ to the Northern Argentinean Patagonia (43 to $44^{\circ} \mathrm{S}$ ) (Carcelles 1940, Castellanos \& Menni 1969, Ré \& Taylor 1981).

\footnotetext{
- Present address: School of Fisheries/Center for Quantitative Sciences, HR-20, University of Washington, Seattle, Washington 98195, USA
}

It reaches its highest densities in the intertidal and shallow subtidal area (down to $15 \mathrm{~m}$ ) of the San Matías Gulf, Argentina ( 40 to $42^{\circ} \mathrm{S}$ ). The spawning and brooding season runs from fall to spring. There is no pelagic larval stage; the relatively large benthic hatchlings settle immediately and reach their adult size at the end of the following summer (Iribarne unpubl.).

Since female octopuses use shelter while brooding their eggs, the shelter not only affects the organism's chance of survival, but it may also affect its reproductive output. Reproductive success may be limited by shelter availability. The actual brooding area provided by a given shelter may also depend on its quality (shape, condition, etc.), which in turn may control fecundity.

The following questions are addressed in this study: (1) Is shelter use a function of size, sex or sexual maturity? (2) Is fecundity affected by shelter type or shelter quality? (3) Can shelters be considered a limiting resource in this area? (4) If so, are shelters equally limiting over the octopus' life span?

\section{MATERIAL AND METHODS}

Study site and sampling procedures. An octopus population living in an oyster bed at the entrance of San Antonio Bay, Argentina $\left(40^{\circ} 45^{\prime} \mathrm{S}, 65^{\circ} 55^{\prime} \mathrm{W}\right)$ 
(Fig. 1) was sampled monthly from August 1986 to June 1987. The inner bay, where the semiduurnal tidal regime exposes ca $80 \%$ of the area, has an extended intertidal flat with creeks and channels. The main channel connecting the bay to the San Matías Gulf, where the oyster bed is located, is dominated by a shallow sandy subtidal bottom ( 1 to $12 \mathrm{~m}$ ). Specimens were collected by SCUBA diving. Due to the strong tidal current (up to 3 knots) collection was restricted to a few hours around low tide. Octopuses were taken by 2 procedures: (1) swimming randomly and collecting all the individuals found, or (2) sampling along transects. In the latter, divers laid down a $100 \mathrm{~m}$ long rope, divided into 10 equal parts. The sampled strp extended $1 \mathrm{~m}$ to each side of the rope. Octopuses found in each sampling unit $\left(10 \mathrm{~m}^{2}\right)$ were counted and collected. Individual octopuses, together with their shelters, were kept in separate plastuc bags. When possible, 100 individuals were gathered each month. Shelters were returned to the sampling area after being examined.

Individuals were sexed and the following measurements were taken: total weight (TW), and dorsal mantle length (DML). Sexual maturity was determined on a 5-stage maturity scale for females, and 3-stage scale for males (Pujals 1982 with minor modifications). These scales are based on the ratio between weight of the testis (tW) and the Needham sac (NW) (males), and between werght of oviductal gland (odW) and the ovary (oW). Matunty undex was calculated as $\mathrm{M}=$
$N W /(t W+N W)$ (males) and $M=o d W /(o d W+o W)$ (females).

The female maturity (M) scale utilized is as follows: $M 0$ (immature): $M \geq 0.3 ; M 1$ (incipient maturity): $0.3 \geq$ $M \geq 0.15 ; M 2$ (medium maturity): $0.15 \geq M \geq 0.06 ; M 3$ (full maturnty): $0.06 \geq M \geq 0.02 ; \mathrm{M} 4$ (post spawning): $M \geq 0.3$, distended empty ovary with grey color. Spawned eggs were counted. Mature individuals found laying eggs were scaled as $M 3 / 4$. The number and location of eggs in the shelter were recorded.

The male maturity scale is as follows: M1 (immature): $M \leq 0.129 ; M 2$ (mature): $M \geq 0.130$, testicles increasing volume, Needham complex very well differentiated, with spermatophores in the penis; M3 (postspermatophonc): $M \geq 0.130$, similar to the previous stage but without spermatophores in the penis.

Objects presumed suitable as shelters were identifıed, and different measurements were taken depending on the type of shelter. Total length, total width and volume of empty bivalve shells were measured. The general aspect of the shells was recorded, and particular attention was given to whether or not the 2 valves were held together by the ligament. Total length, peristomial length and volume of gastropods shells were measured. Total height, total width, maximum diameter and volume of barnacles were measured. Other potential shelters such as cans and bottles were also measured (sıze and volume). Volume was assessed in 2 ways: (1) barnacles and cans were filled with water, whose volume was subsequently measured, (2) volume

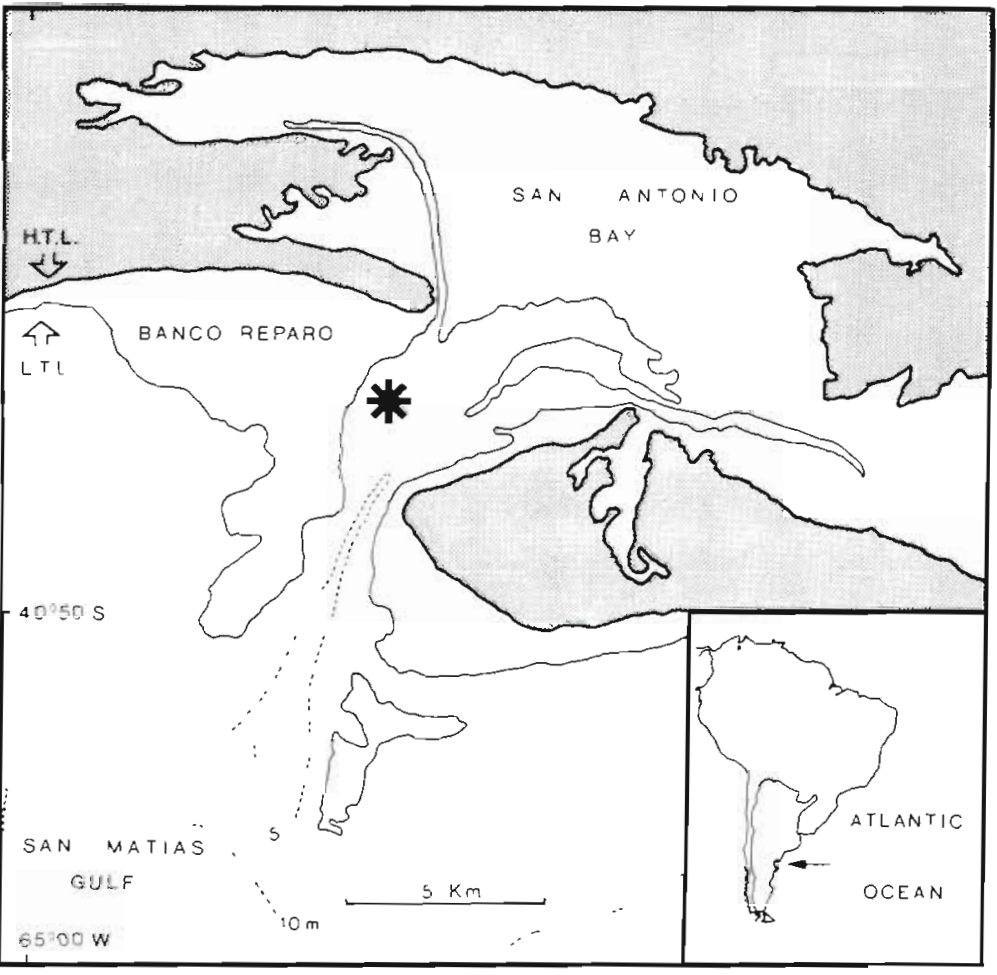

Fig. 1 Location of the sampling area (star) in San Antonio Bay. Inset shows the location of the area in the SW Atlantic Ocean. H.T.L.: high tide level; L.T.L.: low tide level 
of bivalves was calculated as the difference between the amounts of water displaced by the 2 empty valves and by a living bivalve of corresponding size.

Refuge quality was categorized as:

'Shelter type 1': bivalves with the 2 valves held together by an intact ligament, and unbroken gastropods and barnacles.

'Shelter type 2 ': broken barnacles and gastropods, and refuges made up by shells fragments or other objects.

\section{RESULTS}

\section{Field observations}

Only a few octopuses were seen outside their refuges during the whole sampling period at low tide (more than 200 h of daylight underwater observations). When shelters were handled by divers, females always remained hidden without any attempt to escape, while males often left the shelter.

Shelters were mostly of biological origin. The proportions of the different types of shelter remained similar through the study period (Fig. 2). The highest percentage of shelters utilized (50 to $75 \%$ ) corresponded

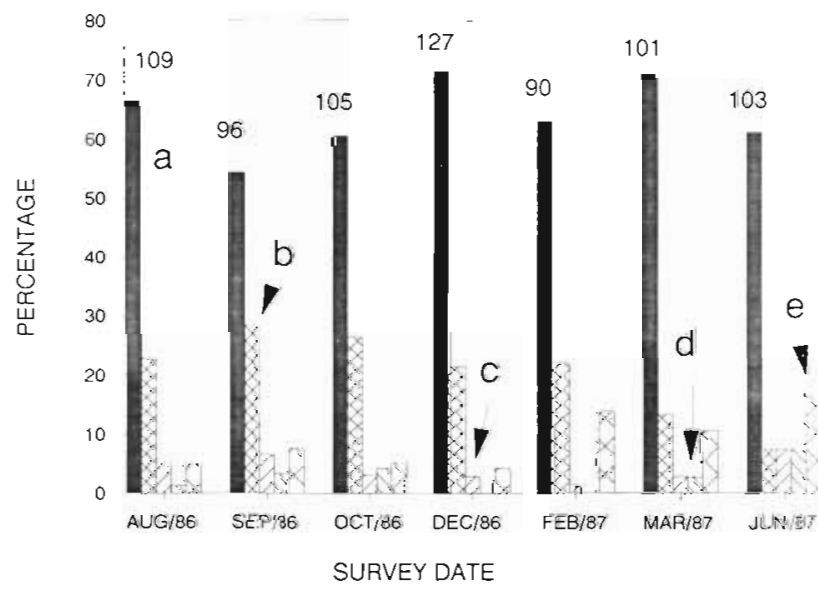

Fig. 2. Octopus tehuelchus. Number of individuals sampled in each survey and percentage of each type of shelters utilized. a: Ostrea puelchana; b: Pitar rostratus plus Amiantis purpurata; c: Balanus sp.; d: gastropods; e: others, mostly made up of parts of shells

to shells of the flat oyster Ostrea puelchana d'Orbigny, an epibenthic oyster with the right valve concave and the left valve flat. Two equivalve clams, Amiantis purpurata (Lamarck) and Pitar rostratus (Koch), very alike in shape and size, ranked second. Gastropod shells, including Buccinanops gradatum (Deshayes), Odontocymbiola subnodosa (Leach) and Zidona dufresnei
(Donovan), were common refuges, but made up less than $9 \%$ of the refuges utilized.

Among shelters advected by tidal currents, shells of Balanus sp. were the most important. Shells of the mussel Mytilus edulis platensis d'Orbigny, the scallop Chlamys tehuelchus (d'Orbigny) and the clam Protothaca antiqua (King) were scarce.

Valves of bivalves that inhabit the oyster bed used as shelters were generally undamaged and held together by the ligament (i.e. Type 1 shelter). Valves of advected bivalves were usually separated, and were often utilized as part of shelters categorized as Type 2.

There was no evidence of competition with other species for the use of shelters. Hermit crabs were comparatively small and competition with small octopuses was not observed.

\section{Relationship between octopus size and shelter size}

Only shelters that were clearly identifiable and in good condition are considered here, generally corresponding to shelter Type 1. Post-spawning females were excluded from analysis due to their wide variation in weight.

Oyster shells being utilized as refuges by octopuses were easily recognized: their valves were more separated than in live specimens, and were generally half buried in the sand on the umbonal end. Oyster length and octopus weight was highly correlated $(r=0.615$, $\mathrm{n}=53, \mathrm{p}<0.0005$ ) (Fig. 3a), but oyster volume and actopus weight were not related $(\mathrm{r}=0.13, \mathrm{n}=53$, $\mathrm{p}>0.5)$. The oyster shells were rarely totally closed, which makes the volume of a closed individual a poor predictor of the actual shelter volume.

Octopuses sheltering in Pitar rostratus or Amiantis purpurata were more difficult to identify, but the reclining position of the shell, unusual for living clams, was a good clue that they were occupied by an octopus. Due to their similarity in size and shape, these 2 species were analysed together. In this case refuge volume showed a high correlation with octopus weight ( $r=0.624, n=69, p<0.0005$ ) (Fig. 3b)

Octopuses sheltering in Balanus sp. were easily identified; the shell entrance was usually blocked with small objects. The volume showed a strong linear relationship with octopus weight $(\mathrm{r}=0.931, \mathrm{n}=17$, $\mathrm{p}<0.0005$ ) (Fig. 3c).

Due to the relationship between octopus size and shelter volume and to the size range of different available shelter types, the relative importance of the different shelters changed over the octopus' life span (Fig. 4). Small individuals used oyster and gastropod shells; later, gastropods were gradually replaced by shells of Pitar rostratus, Amiantis purpurata, and Ostrea puel- 

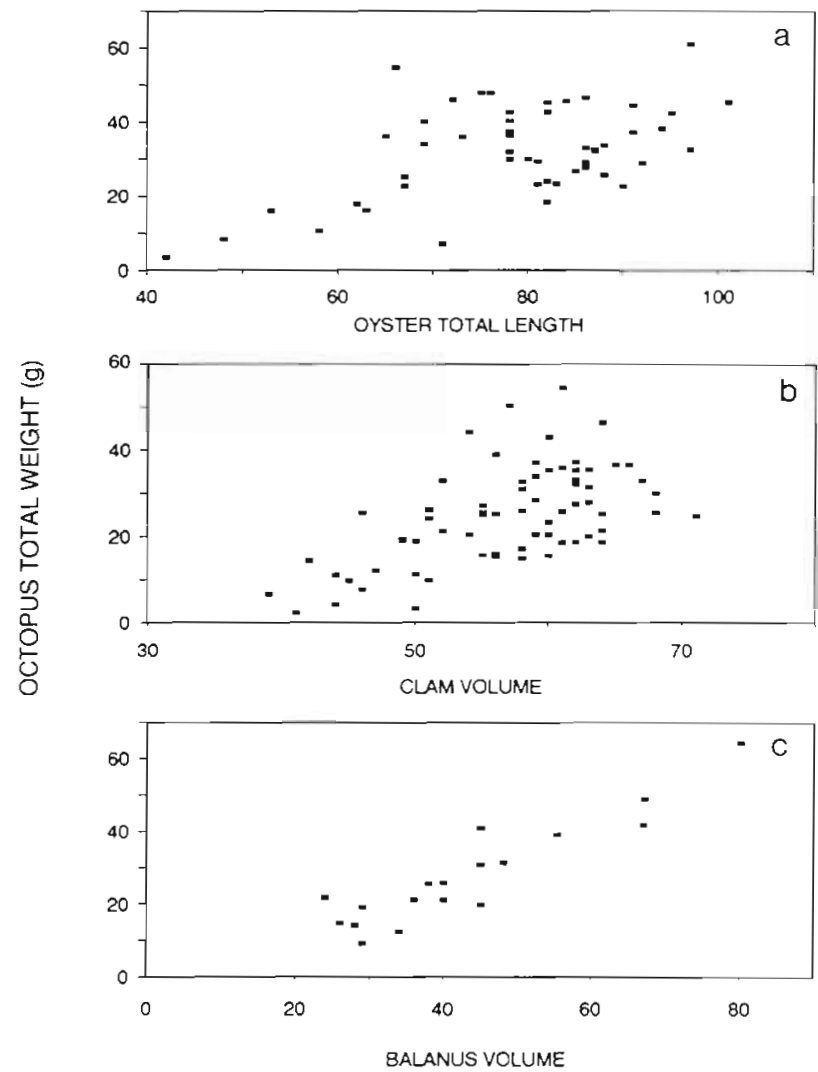

Fig. 3. Octopus tehuelchus. Relationships between (a) total length of oysters Ostrea puelchana used as refuge and octopus weight (g), (b) total volume of Pitar rostratus or Amiantis purpurata used as refuge and octopus weight (g), and (c) total volume of Balanus sp. used as refuge and octopus weight $(\mathrm{g})$

chana. Individuals heavier than $65 \mathrm{~g}$ used mostly shelters composed of mixed sources, and to a lesser extent oyster shells.

\section{Shelter availability and utilization}

The size distribution of available and used shelters differed significantly among the main types (Ostrea puelchana, Fig. 5; Pitar rostratus + Amiantis purpurata, Fig. 6; and Balanus sp.). Octopuses only used the larger classes of the available size range. The larger shelters were rarely unoccupied (Figs. 5 and 6)

\section{Shelter quality and sexual maturation}

Females used Type 1 shelters more often ( $85 \%$ ) than males $(55.3 \%)$ (Fig. 7). The proportion of different shelter types used changed little or not at all during the male's reproductive cycle (Fig. 7 , upper). In contrast,

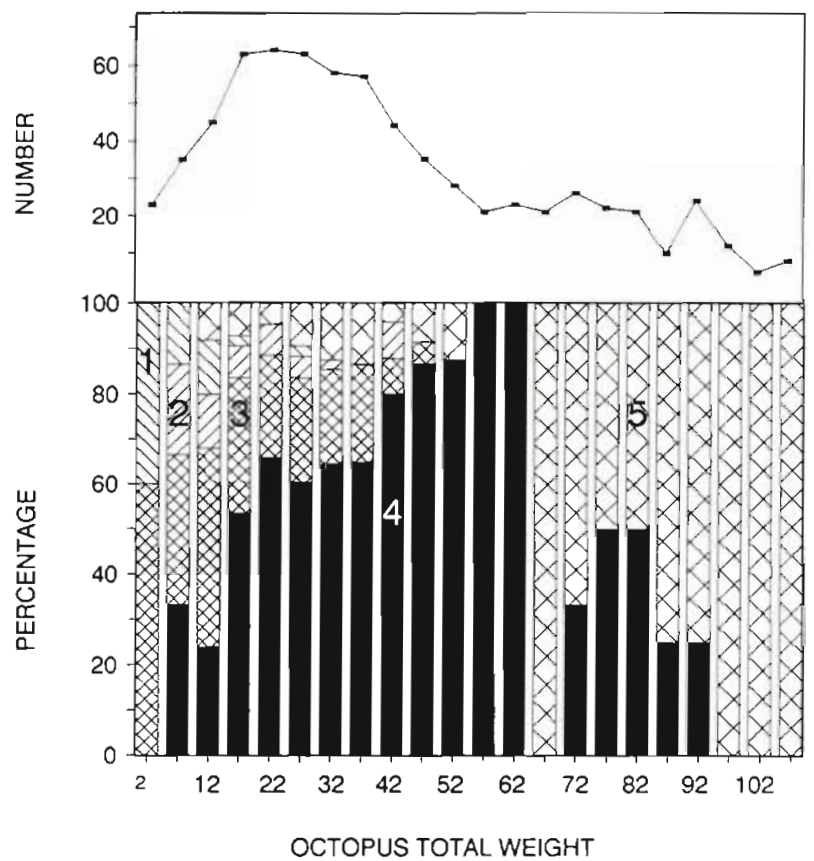

Fig. 4. Octopus tehuelchus. Upper: Number of individuals analyzed; lower: percentage of different types of refuge used per interval of weight (g). 1: gastropod; 2. Balanus sp.; 3: Pitar rostratus or Amiantis purpurata; 4: Ostrea puelchana; 5: others, mostly mixed shelters

females used more Type 1 shelters when they began to lay eggs (M3/4) or brood (M4) (Fig. 7, lower).

\section{Shelters used for brooding and patterns of egg laying}

Most brooding females used empty shells of Ostrea puelchana (Fig. 8). A high percentage (ca 90\%) of eggs were attached to the concave shell. The proportion attached to the flat shell increased with fecundity (Fig. 9).

Shells of Pitar rostratus and Amiantis purpurata were used for brooding shelters less often (and by smaller females) than those of oysters. In this case eggs were evenly distributed between the 2 valves $(\mathrm{n}=23$, $\left.\chi^{2}=44.98 ; \mathrm{H}_{0}=1: 1, \chi^{2}(0.005,22)=42.79, \mathrm{NS}\right)$ (Fig. 10). As in oysters, they were attached to the most concave part of each shell.

Barnacles were less frequently brooding shelters. Eggs were always attached to the deepest part of the shell. Similar patterns of egg attachement were observed in cans or bottles.

\section{Fecundity and shelter quality}

The maximum number of eggs per female was 170 . The relationships between octopus TW, DML, and 


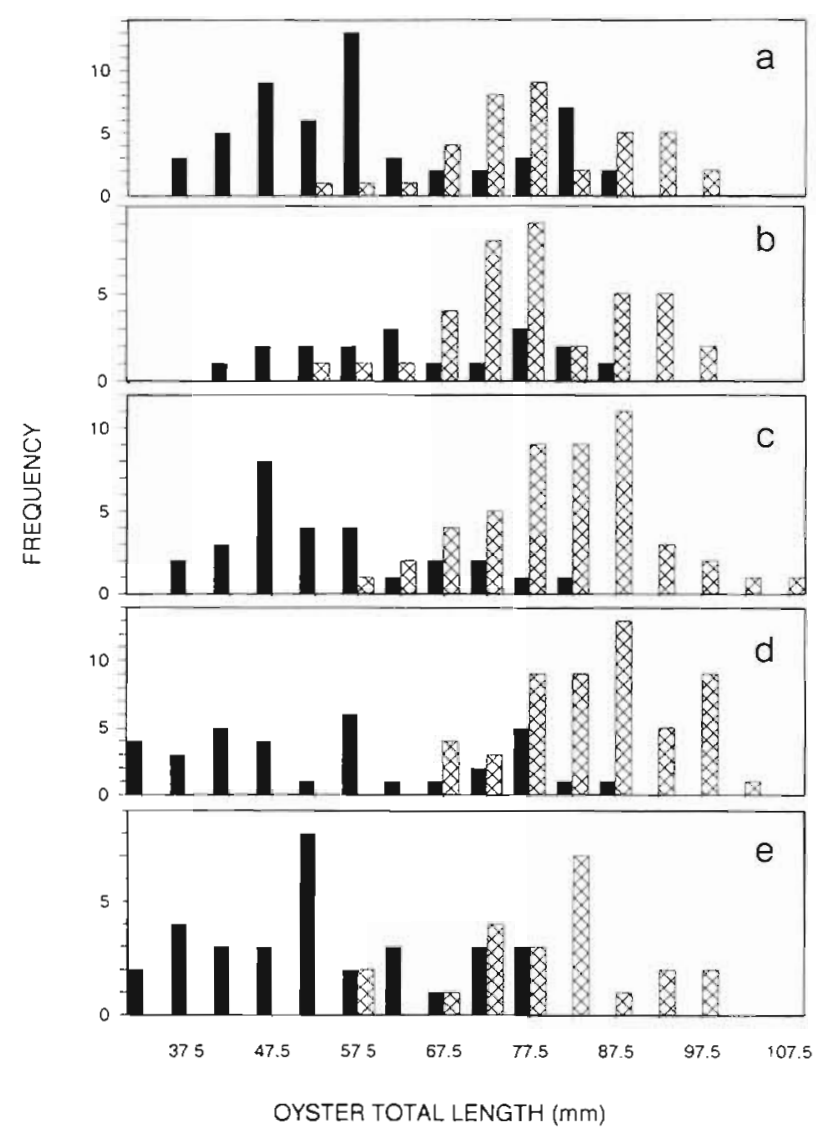

Fig. 5. Relation between the size distribution of used (crosshatched bars) and available (black bars) oysters (Ostrea puelchana) as shelters. (a) September; (b) October; (c) December; (d) February; (e) March

number of eggs were best described by the following functions:

$$
\begin{aligned}
\text { Eggs }= & -360.458(\mathrm{SD}=36.17) \\
& +117.91(\mathrm{SD}=24.25) \ln \mathrm{DML}(\mathrm{mm}) ; \\
& \mathrm{r}=0.528, \mathrm{n}=69, \mathrm{p}<0.005 \\
\text { Eggs }= & -127.252(\mathrm{SD}=23.97) \\
& +64.581(\mathrm{SD}=10.68) \ln \mathrm{TW}(\mathrm{g}) ; \\
& \mathrm{r}=0.541, \mathrm{n}=69, \mathrm{p}<0.005
\end{aligned}
$$

However, when brooding females were separated according to the quality of their shelter (Fig. 11) females brooding in shelter Type 1 had on average significantly higher fecundity than those brooding in shelter Type 2 ( $\overline{\mathrm{x}}$ Type $1=105.27, \mathrm{SD}=42.36, \mathrm{n}=43$; $\overline{\mathrm{x}}$ Type $2=71.35, \mathrm{SD}=34.11, \mathrm{n}=26 ; \mathrm{t}_{\mathrm{c}}=3.46,43 \mathrm{df}$; $0.001<p<0.002 ;$ Zar 1984).

\section{DISCUSSION}

Octopus tehuelchus in San Antonio Bay almost exclusively inhabits refuges of biological origin. Shelter

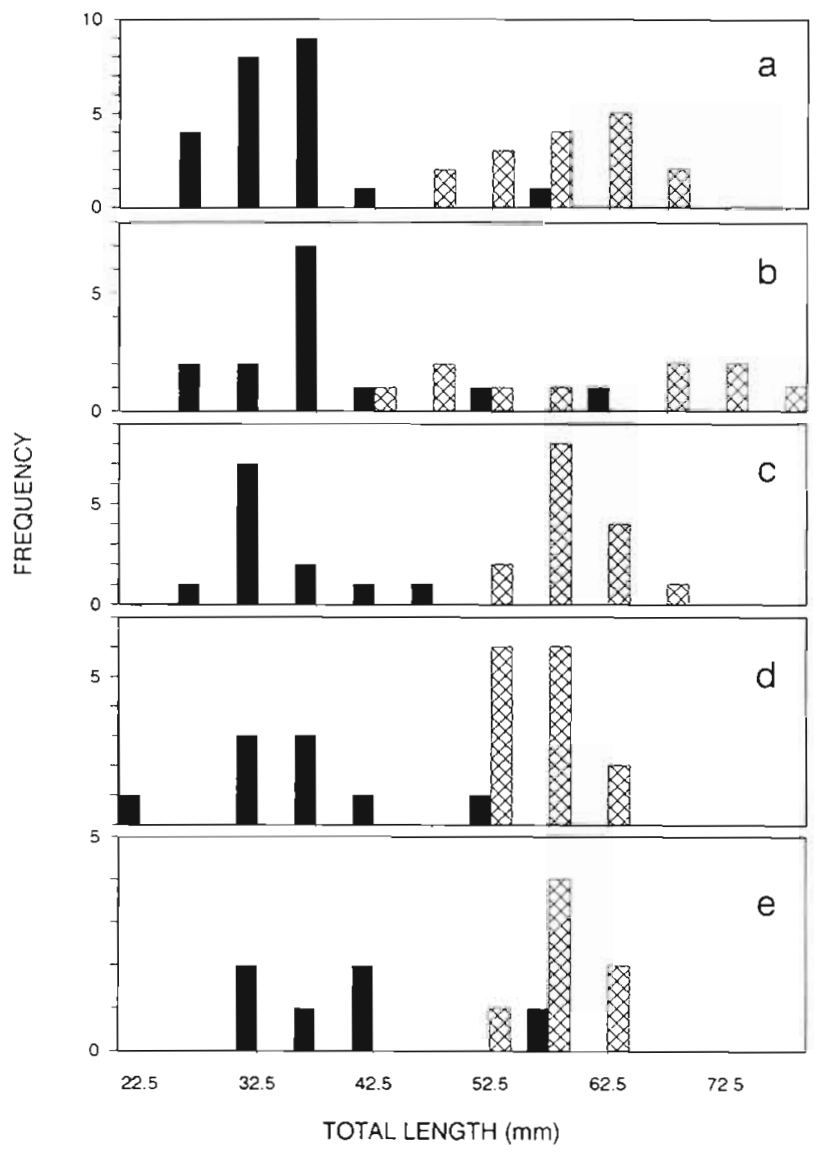

Fig. 6. Relation between the size distribution of used (crosshatched bars) and available (black bars) Pitar rostratus + Amiantis purpurata. (a) September; (b) October; (c) December; (d) February; (e) March

size was directly related to octopus size (or volume). Since available shelter types differ in size, utilization changes over the life span of the octopuses. Small octopuses mainly used shells of gastropods (Buccinanops gradatum), clams (Pitar rostratus and Amiantis purpurata) and flat oysters (Ostrea puelchana). Although small oysters could not be used due to their extremely small volume, large oysters were the almost exclusive refuge of intermediate size octopuses. The only refuges available to octopuses as they grew large were mixed shelters, which may not be the safest: they are visually discernible, increasing the chances of octopuses being detected by predators

Shelters are more limited in supply on soft bottoms than in rocky areas (Ambrose 1982). This is the case on the extended sandy bottom of the northern San Matías Gulf and, particularly, the oyster bed where the study was conducted. Three observations suggest that shelters may be a limited resource, mainly for large octopuses: (1) an increase in the use of mixed shelters with increase of octopus size, (2) the difference between the size distribution of used and available 

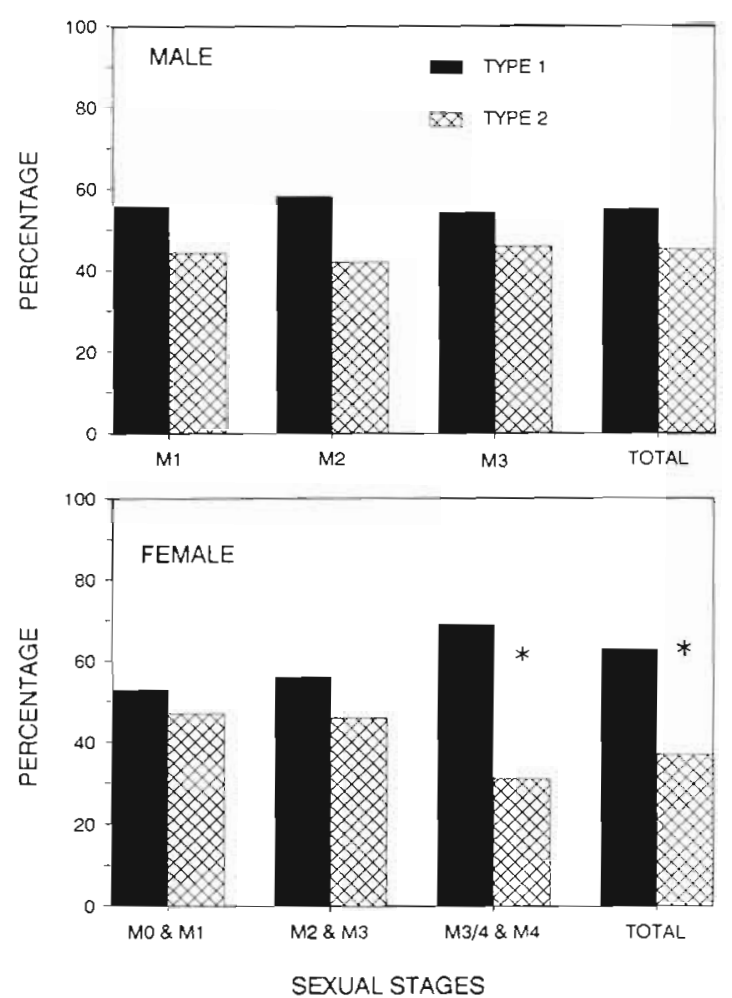

Fig. 7 Octopus tehueichus. Percentage of shelters of different quality used by sexes (male: top; female: bottom) (far right: total) and discriminated by sexual stages. Asterisks denote statistical significance in the binomial test at $p<0.005$ (Conover 1980)

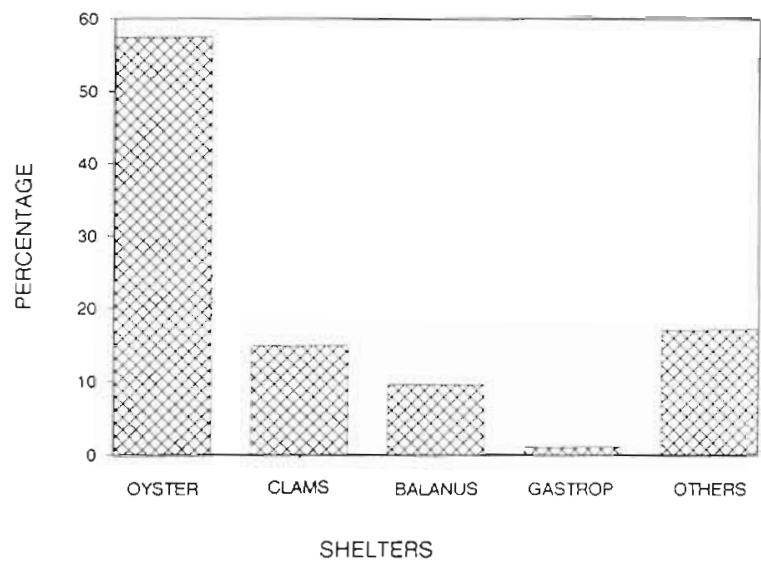

Fig. 8. Octopus tehuelchus. Percentage of females brooding in each type of shelter

shelters, and (3) frequent use of man-made objects such as cans, bricks and tires to catch octopuses in the same area (pers. obs.).

Octopus tehuelchus broods its eggs like other octopus species; females protect and keep their eggs clean throughout the whole of embyonic development. Brooding is usually associated with small adult size in order for females to be able to ventilate and hold all the

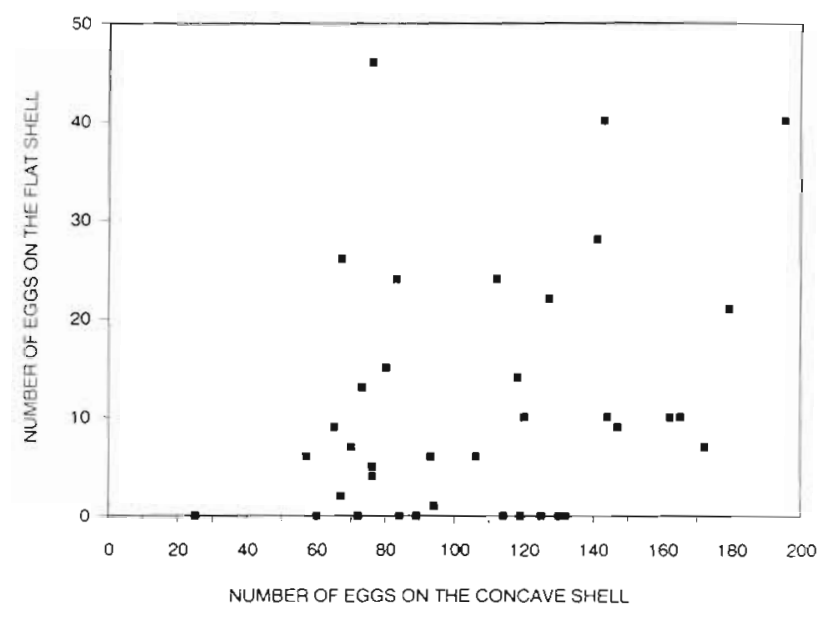

Fig. 9. Octopus tehuelchus. Number of eggs attached to each valve of oyster shells (Ostrea puelchana) utilized for brooding. Dotted line: equal numbers

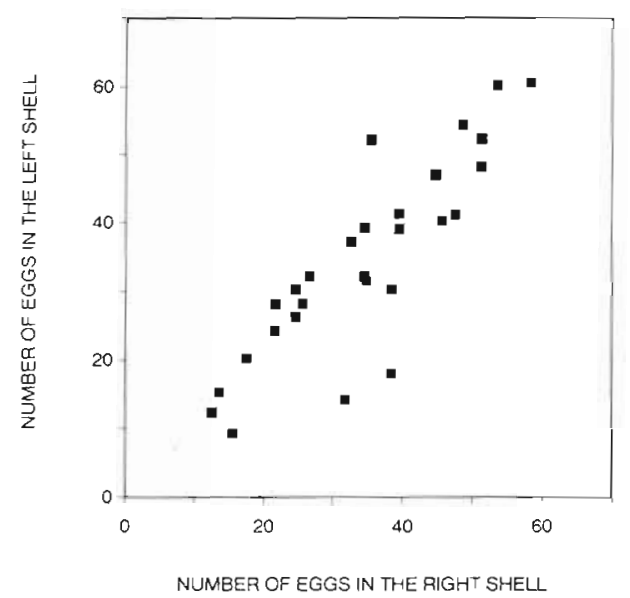

Fig. 10. Octopus tehuelchus. Number of eggs attached to each valve of Amiantis purpurata + Pitar rostratus shells utilized for brooding

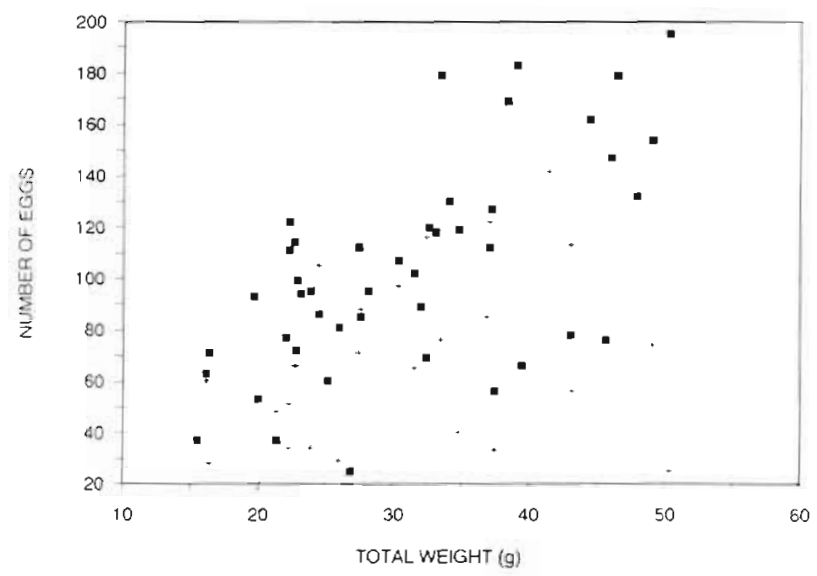

Fig. 11. Octopus tehuelchus. Number of eggs in relation to total weight of brooder females sheltering in (-) good quality shelters and $(+)$ poor quality shelters 
eggs that they produce (Strathmann 1985). Since octopuses lack any brooding device, shelters are used for brooding. This enhances the importance of shelters, which potentially affect the individual's reproductive output.

Requirements for shelter differ between sexes. Both sexes in this semelparous and seasonal spawner species mature almost at the same time (Pujals 1982). It can be hypothesized that the adaptive value of using shelters may change during the octopus' life span depending on the sex of the individual. Before mating, shelters may be equally valuable for both sexes. After mating, however, the usefulness of shelters may be greater to females, since they brood their eggs.

Mature male Octopus rubescens Berry that had discharged all the spermatophores rarely used shelters (Dorsey 1976). In contrast, males of O. tehuelchus use a similar type of shelter throughout their life span. However, females greatly increased the use of good quality shelters when they reached maturity. This pattern may be the consequence of different requirements of shelters by females, but it does not suggest any particular behavior in males.

If fecundity increases with body volume, but the capacity for ventilating eggs increases in proportion to surface area, the difficulty of brooding all the offspring that an individual can produce will increase with individual size (Strathmann 1985). Although this idea was developed mainly for internal brooders, octopuses, mostly species with large eggs like Octopus tehuelchus, may also face this problem. The pattern of laying eggs in oyster shelters, with higher percentage of eggs placed on the concave valve, and the pattern on clam shells (with equal amount of eggs in each concave valve) may increase the size of the brood. Females brood their eggs by cleaning, ventilating and protecting them until they hatch. A concave area may allow more eggs to be reached and protected with the same arm length, resulting in ventilation and care of a relatively larger number of eggs for a given body size. $O$. joubini (Hanlon 1983) also lays eggs in the most concave part of valves.

Whether or not fecundity varies with shelter quality in other octopus species is unknown. The variation in fecundity in Octopus tehuelchus suggests that shelter quality is important. Fecundity was highest for females brooding in a high quality shelter. This may be attributed to at least 2 factors. When refuges are constructed with various objects, the mature female may have to invest some energy in holding the parts together - energy which would otherwise be allocated to egg production. Females brooding in a low quality shelter may also have a higher risk of egg predation and loss of eggs with dislodgement of part of the refuge.
For species that must use refuges to protect themselves from predators, the size of the individual may impose constraints on its ecology. Larger individuals cannot fit in small refuges, while small individuals fit in larger refuges, but remain exposed and lose the possible advantage of being small. In San Antonio Bay, availability of shelters is more limiting for large than for small octopuses. This is consistent with the fractal geometry nature of the substrate (Caddy 1986): smaller organisms have more shelters than larger ones. Large octopuses may thus have less protection and lower quality refuges in which to brood their eggs. However, size also limits reproductive capacity; small individuals produce fewer eggs than larger ones. If the ultimate size that the octopus attains is genetically controlled, it may be expected that in the San Antonio Bay large size may experience negative selection.

Refuges were almost exclusively provided by bivalves. Since octopuses do not feed on these bivalves (unpubl. obs.), they cannot acquire their own shelters through predation. Refuges are supplied through natural mortality of source species. Furthermore, shells of recently dead bivalves may form better quality refuges than old disassembled shells. The life-span of shells held together by the ligament varies depending on factors that affect the rate of decomposition of the ligament (Orensanz et al. 1990). Good quality refuges can be expected to have a short life span as a result of high summer temperatures and water energy. The state of these shelters may in turn play an important role in shaping the population dynamics of this small brooding octopus.

Acknowledgements. This study benefited from ideas and criticism of J. M. Orensanz and A. M. Parma. I thank N. Dieu, T Cacho, E. Zampatti, A. Bocca, M. Lasta, M. A. Pascual and M Fernandez for technical assistance. V Gallucci, A. Kehn, M. Pascual, B. Doumbauldt and A. Anganuzzi made helpful comments on draft of this manuscript. Two anonymous reviewers contributed greatly to the accuracy and clarity of the manuscript. This study was supported by the Rio Negro Province, the National University of Comahue (Argentina) and the Tinker Foundation (US)

\section{LITERATURE CITED}

Altman, J. S. (1967). The behaviour of Octopus vulgaris Lam in its natural habitat: a pilot study. Underwater Ass. Rep., 1966-67: 76-83

Ambrose, R. (1982). Shelter utilization by the molluscan Cephalopod Octopus bimaculatus. Mar. Ecol. Prog. Ser. 7 : $67-73$

Bierens de Haan, J. A. (1926). Versuche über den Farbsinn und das psychische Leben von Octopus vulgaris. Z. vergl Physiol. 4: 766-796

Caddy, J. F. (1986). Modelling stock-recruitment processes in Crustacea: some practical and theoretical perspectives Can. J. Fish. Aquat. Sci. 43: 2330-2344 
Carcelles, A. (1940). Catalogo de los Moluscos marinos de Puerto Quequén (Rep. Argentina). Rev. Mus. La Plata (Argentina) (Zool.) 2: 1-267

Castellanos, Z. A. de, Menni, R. (1969). Sobre dos pulpos costeros de la Argentina. Neotrópica 15: 89-94

Conover, W. J. (1980). Practical nonparametric statistics, 2nd edn. John Wiley \& Sons, Inc.

De Rusha, R. H., Forsythe, J. W., Hanlon, R. T. (1988). Laboratory growth, reproduction and life span of the Pacific pygmy octopus, Octopus digueti. Pacif. Sci. 41: 104-121

Dorsey, E. M. (1976). Natural history and social behaviour of Octopus rubescens Berry. M.Sc. Thesis, Univ. Washington, $44 \mathrm{pp}$

Eibel-Eibesfeldt, I., Scheer, G. (1962). Das Brutpflegeverhalten eines weiblichen Octopus aegina Gray. Z. Tierpsych. 19: $257-261$

Hanlon, R. T. (1983). Chapter 15 Octopus briareus. In: Boyle, P. R. (ed.) Cephalopod life cycles, Vol. 1. Academic Press, London, p. 251-276

Hartwick, E. B., Thorarinsson, G. (1978). Den associates of the giant Pacific octopus, Octopus dofleini (Wulker). Ophelia 17: $163-166$

Hartwick, E. B., Breen, P. A., Tulloch, L. (1978). A removal experiment with Octopus dofleini (Wulker). J. Fish. Res. Bd Can. 35: 1492-1495

Hartwick, E. B., Ambrose, R. F., Robinson, S. M. C. (1984a) Den utilization and the movement of tagged Octopus dofleini. Mar. Behav. Physiol. 11: 95-110

This article was submitted to the editor
Hartwick, E. B., Ambrose, R. F., Robinson, S. M. C. (1984b). Dynamics of shallow-water populations of Octopus dof leini. Mar Biol. 82: 65-72

Mather, J. (1982). Choice and competition: their effects on occupancy of shell homes by Octopus joubini. Mar. Behav. Physiol. 8: 285-293

Mather, J. A. (1982). Factors affecting the spatial distribution of natural populations of Octopus joubini Robson. Anim. Behav. 1166-1170

Orensanz, J. M., Parma, A. M., Iribarne, O. O. (1990). Chapter 11 Dynamics and management of natural populations. In: Shumway, S. E. (ed.) Scallop biology and aquaculture. Elsevier, Amsterdam (in press)

Pujals, M. A. (1982). Contribución al conocimiento de la biología de Octopus tehuelchus D'Orbigny (Mollusca: Cephalopoda). An. Soc. Cient. Arg. Serie I - Ciencias 46: $30-71$

Ré, M. E., Taylor, R. (1981). La pesca de pulpos in Argentina. Artes de captura utilizadas y estadísticas pesqueras hasta 1978. CENPAT (Argentina), Contribución $\mathrm{N}^{\circ} 52$

Strathmann, R. R. (1985). Feeding and nonfeeding larval development and life-history evolution in marine invertebrates. A. Rev. Ecol. Syst. 16: 339-361

Van Heukelen, W. F. (1973). Growth and life-span of Octopus cyanea (Mollusca: Cephalopoda). J. Zool. 169: 299-315

Zar, J. H. (1984). Biostatistical analysis. Prentice-Hall, Inc., Englewood Cliff, New Jersey

Manuscript first received: January 26, 1990

Revised version accepted: June 1, 1990 